\title{
Microbiota and HCV Infection Interplay
}

\author{
Davide Frumento ${ }^{1,2 *}$ \\ ${ }^{1}$ Department of Health Sciences, DISSAL, University of Genova, Genova, Italy \\ ${ }^{2}$ Department of Biomedical and Clinical Science L. Sacco, University of Milan, Italy
}

Submission: February 16, 2018; Published: March 16, 2018

*Corresponding author: Davide Frumento, Infectious Diseases Unit, Hospital San Martino, Largo, Rosanna Benzi 10, 16132 Genova (GE), Italy, Tel: +393334310322; Email: davide.frumento@edu.unige.it

\section{Abstract}

Hepatitis C virus (HCV) is held responsible for about $17.5 \%$ of acute hepatitis cases and after acute infection, roughly $65 \%$ of patients develops a chronic infection. Intestinal microbiota's relevance in the pathogenesis of HCV-induced chronic liver diseases is a promising topic within scientific community. Anyway, its role in chronic HCV infection is still not completely unraveled and it needs more detailed investigations. Although results on relationships standing between human microbiota and HCV infections are lacking, the few published articles are highly inspirational for both further studies and theoretical researches, giving a starting substrate to hypothesize the mechanisms underlying the relationships between microbiota and HCV in the context of gut-liver axis. The aim of this short review is to summarize the state of the art of microbiota/HCV interactions and possibily give a novel point of view based on the articles' conclusions, using an eagle-eye perspective that will allow to open a door to new research studies concerning HCV infections.

\section{Introduction}

Several human body districts are colonized by a microbial community and the gathering of these pools makes up the microbiota. This huge population is formed by bacteria, fungi and these microorganisms are extimed to outnumber human cells [13]. Human physiological status greatly depends on microbiota, in fact it presence is necessary for a normal development, as well as for supporting immune system in the protection of the host from pathogens $[4,5]$. Intestinal microbiota's relevance in pathogenesis of HCV-induced chronic liver diseases is a rising topic among scientific community. Anyway, its role in chronic hepatitis $\mathrm{C}$ virus (HCV) infection is still unclear and it needs more focused studies [6]. Microbiota nutritionally competes with pathogens for resources and colonization sites and it gives fundamental signals for immune priming, sustaining immune system correct development [7-10]. It has a controversial role, since it can limit or promote viral infection, or have no effect, but direct or indirect effects on viral infection itself can take place. For example, microbiota (or its metabolites) may interact with viral particles, altering response or infectivity [11-14]. Intestinal microbiota has also been recognized to have a pivotal importance in autoimmune diseases such as type 1 diabetes (T1D) [15-17]. The aim of this short review is to reassume the state of the art of microbiota/HCV interactions and possibily give a novel point of view based on the reviewed studies, using an eagle-eye perspective.

\section{The HCV infection}

Hepatitis C virus (HCV) is held responsible for about $17.5 \%$ of acute hepatitis cases and it was reported that, after acute infection, roughly $65 \%$ of patients develops a chronic infection [18]. According to the WHO (World Health Organization) statistics, HCV is currently infecting about 170 million people worldwide. Patients suffering from Chronic Hepatitis C (CHC) have a high probability to develop serious complications, i.e. cirrhosis and hepatocellular carcinoma (HCC) [19-21]. Under an epidemiological point of view, it was reported that HCV is associated with several extrahepatic manifestations such as type 2 diabetes mellitus, insulin resistance, oral manifestations and glomerulopathies [22-25].

\section{Microbiota and viral infections}

Since microbiota typically colonizes sites used by viruses to introduce their selves into hosts, its presence can is some cases affect the infection outcome. It was in fact reported that the commensal microbiota of Aedes aegypti (an insect vector) indirectly mitigates Dengue viral transmission [26]. Mosquitoes in which the commensal population is killed by antibiotic molecules show higher viral titers with the respect to those in which antibiotics are not administered. Moreover, mosquitoes having their natural microbial population highly express a broad set of immune-related genes, such as those encoding antimicrobial peptides modulated by Toll-like receptor (TLR) pathway (Xi et al. 2008).

On the other hand, while it is true that microbiota can be pivotal to fight viral infections and therefore shift the infective process balance, it may also enhance viral infection, either in a direct or indirect way. Previous studies demonstrated the indirect promoting activity exerted by microbiota on virus 
replication, i.e. the viral infection enhancing via the proliferative stimulation or target cells activation [27]. Moreover, this concept is especially applicable for retroviruses targeting proliferating cells, in fact, murine leukemia virus (MuLV)-infected germ-free mice are show a mild resistance to virally induced leukemia if compared to conventional murine models $[28,29]$. Conversely, sheep red blood cells-immunized MuLV-infected mice show a significant increase in leukemia development, comparable to that of infected specific pathogen free (SPF) mice [29]. Previous investigations show that viruses belonging to three distinct families partially depend on commensal microorganisms in order to perform an efficient replication/transmission process $[30,31]$. Kuss et al. [30] demonstrated that poliovirus-susceptible mice administered with antibiotics exhibit lower mortality rates after poliovirus infection if compared to untreated ones. Relevantly, virus replication in murine guts is highly relying on microbiota, in fact antibiotic-treated and germ-free mice secrete poorly virulent viruses. Both Gram-positive and Gram-negative bacteria incubated with poliovirus highly promote its infectivity in cultured cells. Such a phenomenon does not need live bacteria, because surface polysaccharides, like peptidoglycan (PG) and lipopolysaccharides (LPS), are sufficient to exert such an effect on viral infectivity. Significantly, these results were not solely related to poliovirus, since the reovirus infection was found to be more severe if gut microbial population were present.

\section{HCV and microbiota}

To date, Pubmed Archive (www.ncbi.nlm.nih.gov/pubmed/) reports few researches on relations standing between HCV and microbiota have been published. Yet, this interplay was not fully understood. One of the most recent published studies reported that intestinal microbiota of 95 patients chronically infected with HCV, with and without cirrhosis, greatly differs between cirrhotic and non-cirrhotic patients. Moreover, this study highlighted that the stage of both HCV infection and liver disease is linked with a lowered alpha diversity, and it was inferred that this could be due to a direct cross-talk between HCV and host's bacterial populations or indirect relations enhanced by immune system [32]. So, this is an example in which microbiota could be held responsible of easing both viral activity once patient is infected and stage of cirrhosis. So, phylotypes number appear to be inversely proportional to the occurred complications.

Interestingly, it was demonstrated that mucosal gut microbiota composition is altered in patients with Chronic Hepatitis C (CHC) with respect to cirrhotic ones and those suffering from hepatocellular carcinoma (HCC). An increase of Proteobacteria and a reduction of Bacteroidetes and Firmicutes phyla was reported in CHC, HCC and cirrhotic individuals, suggesting the existence a pathogenic role of gut microbiota in the HCV-related liver disease and HCC development [33]. So, in this case, a precise unbalance in bacterial populations is correlated with the virus and is long-term complications. Thus, it can be said that preservation of gut microbiota composition, employing various strategies like prebiotics and probiotics seems to be a hopeful instrument for preventing or treating the progress of liver disorders associated with HCV [34-36]. Interestingly, stool samples analyses from six HCV patients and eight healthy individuals gene sequencing showed that the alphadiversity of the healthy individuals gut microbiomes was higher than the patients one. Common points with the above cited work can be found, in fact, although Bacteroidetes were more abundant in HCV subjects, healthy ones had more Firmicutes, Proteobacteria, and Actinobacteria. Moreover, Bifidobacterium (probiotic genus), was only detected in healthy individuals [37]. Plus, a cohort of $105 \mathrm{HCV}$ cirrhotics was examined in order to understand if viral eradication could impact on microbiota composition. No significant differences in overall microbiota diversity (UNIFRAC $\mathrm{P}=0.3$ ) between groups with/without SVR (Sustained Virological Response). So, curing the infection does not bring any variation in gut microbiome [38]. However, results about microbiota analysis of a large population of HCV individuals are lacking.

\section{Conclusion}

It can be concluded that, although researches on relationships standing between human microbiota and HCV infections are lacking, the few published papers are highly inspirational for both further studies and theoretical investigations. As stated above, HCV infection and related liver disorders are influenced by microbiota, namely by loss of bacterial composition balance and lowering of phylotypes diversity. Taken together, these findings allow to point out that the gut-liver axis is very important within the HCV infection context and is particularly influential on its liver complication. It could be therefore useful to perform fecal transplantations on patients that are found in a condition of gut dysbiosis, in order to restore the phyla pattern. It remains unclear if particular microbiota alterations could act as a predisposing factor for an especially aggressive HCV infection or if such an infection causes dysbiosis.

\section{References}

1. Bianconi E, Piovesan A, Facchin F, Beraudi A, Casadei R, et al. (2013) An estimation of the number of cells in the human body. Ann Hum Biol 40(6): 463-471.

2. Hao WL, Lee YK (2004) Microflora of the gastrointestinal tract: a review. Methods Mol Biol 268: 491-502.

3. Whitman WB, Coleman DC, Wiebe WJ (1998) Prokaryotes: the unseen majority. Proc Natl Acad Sci USA 95: 6578-6583.

4. Grice EA, Kong HH, Conlan S, Deming CB, Davis J, et al. (2012) Topographical and temporal diversity of the human skin microbiome. Science 324(5931): 1190-1192.

5. Keijser BJ, Zaura E, Huse SM, van der Vossen JM, Schuren FH, et al. (2008) Pyrosequencing analysis of the oral microflora of healthy adults. J Dent Res 87: 1016-1020.

6. Preveden T, Scarpellini E, Milić N, Luzza F, Abenavoli L (2017) Gut microbiota changes and chronic hepatitis $\mathrm{C}$ virus infection. Expert Rev Gastroenterol Hepatol 11(9): 813-819.

7. Buffie CG, Pamer EG (2013) Microbiota-mediated colonization resistance against intestinal pathogens. Nat Rev Immunol 13: 790-801. 
8. Maynard CL, Elson CO, Hatton RD, Weaver CT (2012) Reciprocal interactions of the intestinal microbiota and immune system. Nature 489: 231-241.

9. Hill DA, Hoffmann C, Abt MC, Du Y, Kobuley D, et al. (2010) Metagenomic analyses reveal antibiotic-induced temporal and spatial changes in intestinal microbiota with associated alterations in immune cell homeostasis. Mucosal Immunol 3: 148-158.

10. Mazmanian SK, Liu CH, Tzianabos AO, Kasper DL (2005) An immunomodulatory molecule of symbiotic bacteria directs maturation of the host immune system. Cell 122: 107-118.

11. Kuss SK, Best GT, Etheredge CA, Pruijssers AJ, Frierson JM, et al. (2011) Intestinal microbiota promote enteric virus replication and systemic pathogenesis. Science 334: 249-252.

12. Robinson CM, Jesudhasan PR, Pfeiffer JK (2014) Bacterial lipopolysaccharide binding enhances virion stability and promotes environmental fitness of an enteric virus. Cell Host Microbe 15(1): 3646.

13. Kane M, Case LK, Kopaskie K et al. (2011) Successful transmission of a retrovirus depends on the commensal microbiota. Science 334: 245249.

14. Miura T, Sano D, Suenaga A, Yoshimura T, Fuzawa M, et al. (2013) Histo-blood group antigen-like substances of human enteric bacteria as specific adsorbents for human noroviruses. J Virol 87: 9441-9451.

15. Vaarala $O$ (2012) Is the origin of type 1 diabetes in the gut? Immunol Cell Biol 90(3): 271-276.

16. Vaarala 0 (2013) Human intestinal microbiota and type 1 diabetes. Curr Diab Rep 13(5): 601-607.

17. Zipris D (2013) The interplay between the gut microbiota and the immune system in the mechanism of type 1 diabetes. Curr Opin Endocrinol Diabetes Obes 20(4): 265-270.

18. Li HC, Lo SY (2015) Hepatitis C virus: virology, diagnosis and treatment World J Hepatol 7(10): 1377-1389.

19. Alberti A, Chemello L, Benvegnù L (1999) Natural history of hepatitis C. J Hepatol 31(Suppl 1): 17-24.

20. Hoofnagle JH (2002) Course and outcome of hepatitis C. Hepatology 36: 21-29.

21. Chen SL, Morgan TR (2006) The natural history of hepatitis C virus (HCV) infection. Int J Med Sci 3: 47-52.

22. Carrozzo M, Scally K (2014) Oral manifestations of hepatitis C virus infection. World J Gastroenterol 20: 7534-7543.

23. Ozkok A, Yildiz A (2014) Hepatitis C virus associated glomerulopathies. World J Gastroenterol 20: 7544-7554.

24. Grimbert S, Valensi P, Lévy-Marchal C, Perret G, Richardet JP, et al.

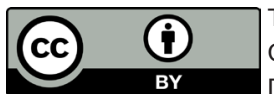

This work is licensed under Creative

Commons Attribution 4.0 License

DOI: 10.19080/CTBEB.2018.13.555852
(1996) High prevalence of diabetes mellitus in patients with chronic hepatitis C. A case-control study. Gastroenterol Clin Biol 20: 544-548.

25. Montenegro L, De Michina A, Misciagna G et al. (2007) Virus C hepatitis and type 2 diabetes: a cohort study in southern Italy. Am J Gastroenterol 108: 1108-1111.

26. Xi Z, Ramirez JL, Dimopoulos G (2008) The Aedes aegypti toll pathway controls dengue virus infection. PLoS Pathog 4: e1000098.

27. Wilks J, Golovkina T (2012) Influence of microbiota on viral infections. PLoS Pathol 8 (5): e1002681.

28. Isaak DD, Bartizal KF, Caulfield MJ (1988) Decreased pathogenicity of murine leukemia virus-Moloney in gnotobiotic mice. Leukemia 2: 540544.

29. Kouttab NM, Jutila JW (1972) Friend leukemia virus infection in germfree mice following antigen stimulation. J Immunol 108: 591-595.

30. Kuss SK, Best GT, Etheredge CA et al. (2011) Intestinal microbiota promote enteric virus replication and systemic pathogenesis. Science 334: $249-252$

31. Kane M, Case LK, Kopaskie K, Kozlova A, MacDearmid C, et al. (2011) Successful transmission of a retrovirus depends on the commensal microbiota. Science 334: 245-249.

32. Heidrich B Vital M, Plumeier I, Döscher N, Kahl S, et al. (2018) Intestinal microbiota in patients with chronic hepatitis $\mathrm{C}$ with and without cirrhosis compared with healthy controls. Liver Int 38(1): 50-58.

33. Sanduzzi Zamparelli M, D’Argenio V, Casaburi G et al. Mucosal gut microbiota composition in patients with HCV infection, from chronic hepatitis to hepatocellular carcinoma. Dig Liver Dis 4952: e73-e223.

34. Adawi D, Ahrné S, Molin G (2001) Effects of different probiotic strains of Lactobacillus and Bifidobacterium on bacterial translocation and liver injury in an acute liver injury model. Int J Food Microbiol 70: 213220.

35. Bajaj JS, Heuman DM, Hylemon PB, Sanyal AJ, Puri P, et al. (2014) Randomised clinical trial: Lactobacillus GG modulates gut microbiome, metabolome and endotoxemia in patients with cirrhosis. Aliment Pharmacol Ther 39: 1113-1125.

36. Chiva M, Soriano G, Rochat I, Peralta C, Rochat F, et al. (2002) Effect of Lactobacillus johnsonii La1 and antioxidants on intestinal flora and bacterial translocation in rats with experimental cirrhosis. J Hepatol 37: 456-462

37. Aly AM, Adel A, El-Gendy AO, Essam TM, Aziz RK (2016) Gut microbiome alterations in patients with stage 4 hepatitis C. Gut Pathog 8(1): 42.

38. Bajaj JS, Sterling RK, Betrapally NS, Nixon DE Fuchs M, et al. (2016) HCV eradication does not impact gut dysbiosis or systemic inflammation in cirrhotic patients. Aliment Pharmacol Ther 44(6): 638-643.

Your next submission with Juniper Publishers
will reach you the below assets
- Quality Editorial service
- Swift Peer Review
- Reprints availability
- E-prints Service
- Manuscript Podcast for convenient understanding
- Global attainment for your research
- Manuscript accessibility in different formats
( Pdf, E-pub, Full Text, Audio)
- Unceasing customer service
Track the below URL for one-step submission
https://juniperpublishers.com/online-submission.php


